\title{
Influence of Behavioral Factors on Mobile Phone Usage among Fishermen: The Case of Pangkor Island Fishermen
}

\author{
Siti Aisyah Bt Ramli ${ }^{1}$, Siti Zobidah Omar ${ }^{1}$, Jusang Bolong ${ }^{1}$, Jeffrey Lawrence D’Silva ${ }^{1} \&$ Hayrol Azril \\ Mohamed Shaffril \\ ${ }^{1}$ Laboratory of Cyber Generation, Institute for Social Science Studies, Universiti Putra Malaysia, Malaysia \\ Correspondence: Siti Zobidah Omar, Laboratory of Cyber Generation, Institute for Social Science Studies, \\ Universiti Putra Malaysia, Malaysia. E-mail: syah_amal@yahoo.com
}

\author{
Received: January 28, 2013 Accepted: March 5, 2013 Online Published: April 27, 2013 \\ doi:10.5539/ass.v9n5p162 URL: http://dx.doi.org/10.5539/ass.v9n5p162
}

\begin{abstract}
The swift evolution of mobile phone technology has benefited various groups within communities. Fishermen, as one of the important groups, particularly in terms of their role in ensuring the nation's food security, rely on mobile phones to conduct their fishing routines. While there is an abundance of studies that explore factors influencing mobile phone usage in various groups of communities, less interest has been placed on mobile phone usage among fishermen. This has driven the current study to its focal objective, which is to determine the behavioral factors that influence the usage of mobile phones among fishermen. This study is quantitative, and surveys a total of 250 registered fishermen from Pangkor Island - one of the main fishing areas in Perak. The results demonstrate that most of the fishermen use mobile phones for safety and communication purposes. In addition, due to a number of problems, fishermen are found to use advanced mobile phone applications such as 3G, Internet and GPS at a minimal level. Further analysis confirms that four behavioral factors, namely performance expectancy, effort expectancy, behavioral intention and social influence, have positive and significant correlations with mobile phone usage.
\end{abstract}

Keywords: mobile phones, fishermen, technology usage, community development

\section{Introduction}

In Malaysia, mobile phones have been used for decades, and have been effectively replaced the traditional means of communicating. In this modern day it is not surprising that new models of mobile phone are launched every month. The mobile phone offers a great deal in narrowing down the digital gap particularly those between the rural and urban people. Digital gap refers to a scenario where differences occur in term of ICT usage between those who are literate and knowledgeable in ICT and those who are not. Such difference can be geared by various factors such as areas, countries, ethnic groups, gender and economic status (Noor Sharifah, 2006).

To minimize the gap, the government has come out with a number of initiatives such as Rural Internet Centre, Community Broadband Centre and Medan Infodesa. Such initiatives have met its objective and albeit placing their investment on these ICT projects, additionally, the government is continually finding ways to encourage and embolden community to use ICT. One of the recognized ways to attract people in using ICT is by offering tools that are germane to their daily tasks and daily life.

The mobile phone is related to the community and offers an abundance of benefits for them. In a general scope mobile phone usage provides chances for the community to create economic opportunities and strengthen social networks, and make the sharing of information and knowledge easier and more effectively (Jensen, 2007). Within its specific scope, the mobile phone does benefit fishermen in a sense that they aid the fishermen to improve their access to information. In their early days, conducting fishing routine and business without such communication devices is challenging and comparatively with the assistance of mobile phone it 'connects' the fishermen with the valuable information with regard to market price, weather and fishing location (Jensen, 2007). In addition, mobile phone helps the fishermen to feel secure while at the sea as it accelerates communication during emergency. Furthermore, mobile phone enhances fishermen communication quality as it allows them to be closer to their families and other fishermen even when they are on the sea (Salia et al., 2011). Though mobile phones have been proven to play an important role in fishermen's daily routines, it seems that these two subjects - fishermen and mobile phones - are not a prime interest of scholars, as there has been a lack of relevant studies 
to date. In response to this gap, this study attempts to explore the behavioral factors influencing mobile phone usage among fishermen.

\section{Fishermen in Malaysia}

Fishermen are an important group in Malaysia, particularly in terms of their role in providing consistent marine supplies for the community. Interest in marine-related jobs, particularly fishermen, is mounted in Malaysia. This is not surprising, as data show that in 2010, a total of 129,622 fishermen were registered, compared to just 97,947 in 2006 (Department of Fisheries Malaysia, 2010). Most of the fishermen in Malaysia can be found in Sabah, Sarawak, Perak and Selangor. There are four categories of registered fishermen; zone A refers to those who conduct their fishing operations within 0.1 to 5.0 nautical miles from shore, zone B refers to between 5.1 to 12.0 nautical miles from shore, zone $\mathrm{C}$ refers to between 12.1 to 30.0 nautical miles from shore, and zone $\mathrm{C} 2$ refers to $>30.1$ nautical miles from shore. Though the number of registered fishermen is encouraging, the government is placing consistent effort in attracting interest from the community, particularly the younger generation, with respect to the fisheries industry. Efforts such as providing every fisherman with a monthly allowance of RM200 (roughly equivalent to USD66) and a petrol/diesel subsidy which allows them to buy their fuel at cheaper prices than usual, have proven to be successful in attracting more involvement from the community in the fisheries industry. Drift nets, trawl nets and fish purse seines are among the main fisheries tools used by fishermen in Malaysia.

Pangkor Island is a well-known tourist area in Malaysia. Activities such as snorkeling, trekking, the Pangkor Suspension Bridge, small and medium enterprises (SMEs) and Homestays can be found here, while famous historical places such as the Kali Amman Temple, Foo Lin Kong Temple, The Dutch Port and Tiger Rock are among the main attractions. Pangkor Island is located in Perak - one of the main marine source suppliers in Malaysia. Although there are a number of job opportunities related to tourism, fisheries industry is one of the main industry preferences for locals to work in and one of the possible reasons for this is that there is still an abundance of fish in the sea in Perak, unlike other areas which have recorded depleting numbers of fish.

\section{The Models Used: Unified Theory of Acceptance and Use of Technology (UTAUT)}

All of the constructs within this study are based on the Unified Theory of Acceptance and Use of Technology (UTAUT) Model. This model was invented by Venkatesh et al. (2003), and was hugely influenced by the established Technology Acceptance Model (TAM). UTAUT consists of six main constructs, namely performance expectancy, effort expectancy, social influence, facilitating conditions, behavioral intention and voluntariness of use (Figure 1).

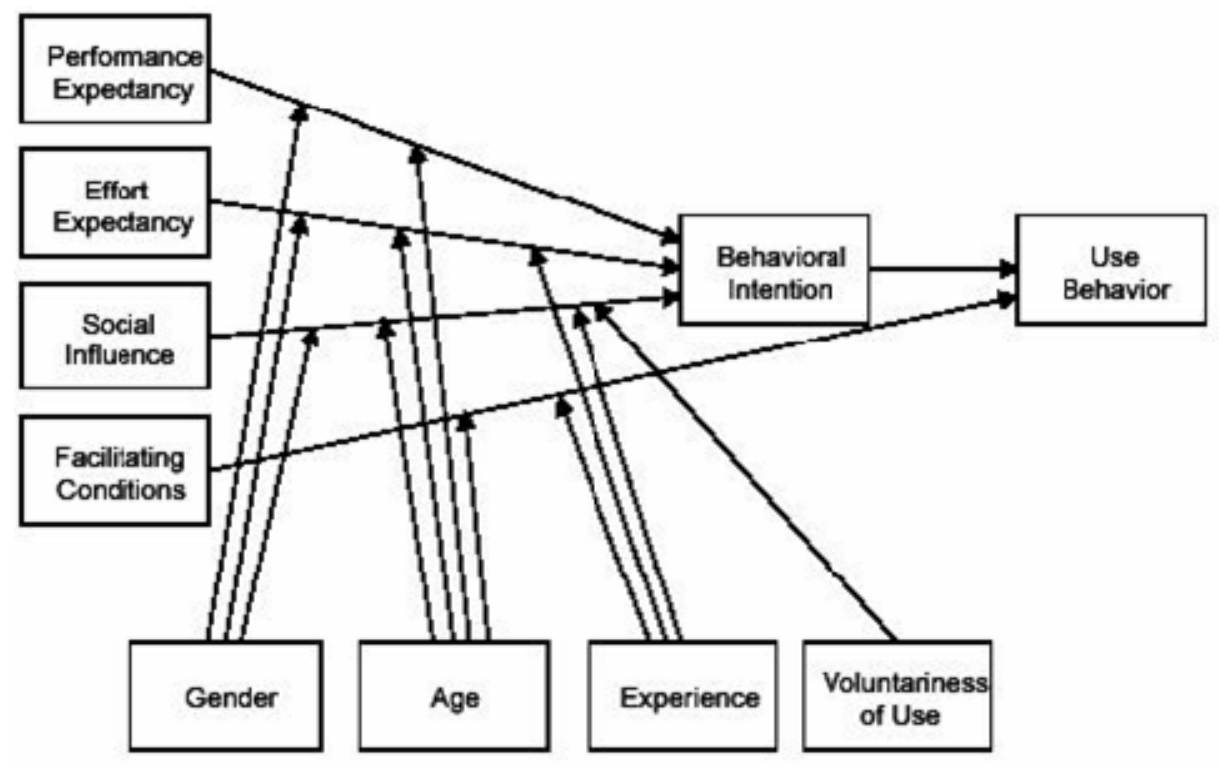

Figure 1. Unified theory of acceptance and use of technology (UTAUT) (Venkatesh et al., 2003)

\subsection{Performance Expectancy (PE)}

$\mathrm{PE}$ refers to the level whereby an individual believes that system usage will aid them to enhance the quality and 
quantity of their job performance. The benefits offered have a huge influence on people's decisions on whether or not to use the technology (Teo, 2008; Abu Hassan, 2011). Moreover, benefits that are in line with the user's interests and needs are the prime priority (Abu Samah et al., 2010). Within this study, PE refers to the benefits of using mobile phones with regards to communication, safety, marketing and entertainment.

\subsection{Effort Expectancy (EE)}

This refers to the level of ease associated with the use of the system. Meso et al. (2005) conclude that perceived ease of use is an important construct for technology usage. As a community perceives the services offered to be easy to utilize, they will be emboldened to use it persistently, which in turn facilitates sustainable usage of the services offered (Rogers, 2003). Within the scope of this study, EE refers to fishermen's perceptions of the ease of using mobile phone applications such as calling, messaging, Internet, 3G, video, music, planner, clock, video recorder and voice recorder.

\subsection{Social Influence (SI)}

Gilligan (2005) and Rouibah (2008) have successfully demonstrated the effectiveness of SI as one of the impingement factors for technology usage. SI refers to the degree to which an individual perceives that important others believe he or she should use a new system. Within the scope of this study, SI is seen as the influence of fishermen's colleagues and family members, as well as agency officers and village leaders, with respect to their use of mobile phones in their fishing routines.

\subsection{Facilitating Conditions (FC)}

This refers to the level at which an individual believes that an organizational and technical infrastructure exists to support the use of a system. Adequate FC provided in an area is believed to encourage the community to use and benefit from the technology (Abu Samah et al., 2010). Within the scope of this study, FC refers to the availability of telecommunications connections, stalls that sell mobile phones (both contract and prepaid), workshops that repair mobile phones, and courses relating to mobile phone usage and repair.

\subsection{Behavioral Intention (BI)}

$\mathrm{BI}$ refers to the subjective probability that an individual will perform the behavior in question. $\mathrm{BI}$ is said to have a huge influence on ICT acceptance and usage (Oye et al., 2012). BI relies heavily on the person's attitude (Zhang and Aikman, 2007). Within the scope of this study, statements to measure BI are based on fishermen's intention to increase their mobile phone usage, to add the number of mobile phones owned, and to add to their mobile phone knowledge. Furthermore, questions with regard to their intention to attend mobile phone courses and encourage their colleagues to use mobile phones in their fishing operations are also included.

\subsection{Voluntariness of Use (VU)}

VU refers to the level of perception that usage of technology is based on free will. In addition, VU refers to situations in which potential adopters perceive the adoption decision to be non-mandated. Fishermen should use mobile phones based on their own intentions, and be free from any forces from concerned parties, such as colleagues and family members. Any force on technology usage is believed to be impractical (Argawal and Prasad, 1999). Within this study, VU regarding mobile phone usage refers to situations in which fishermen's mobile phone usage is free from any force from agency officers, colleagues and family members.

\section{Methodology}

This is a quantitative study whereby a developed questionnaire was employed to gain the required data. The questionnaire was developed based on the literature review and past studies. The questionnaire was made in three parts. Part 1 consists of questions with regard to demographic data of the respondents, part 2 consists of questions with regard to purposes of mobile phone usage among the respondents and part 3 consists of questionnaire with regard to behavioral factors that might influence respondents usage of mobile phone (Table 1). The completed questionnaire then was pre-tested among 30 selected fishermen at Port Dickson, Negeri Sembilan which has resulted in a Cronbach alpha value that exceeded .700 which passed the recommended value by Nunnally (1978). Through a simple random sampling, a total of 250 registered fishermen on Pangkor Island were selected as the respondents for the actual data collection for this study. This number was gained based on $\mathrm{G}^{*}$ Power analysis. Using $\mathrm{G}^{*}$ power analysis, and based on the moderate effect size, an alpha value of .005 and a magnitude of power of between .90-.95, the appropriate sample size against which to run a Pearson product-moment correlation is 191 . This study uses a bigger sample size because, according to Mohammad Najib (1999), a bigger sample size will strengthen the reliability and validate the study. The data collection process was conducted on September 2012, and a number of trained and experienced enumerators were involved. 
In addition, assistance from village leaders, jetty leaders and vessel skippers was used to identify suitable respondents. After successfully gone through the data collection process, then the data were cleaned and analyzed using SPSS whereby descriptive statistics such as frequency, percentage, mean and standard deviation were performed to describe the general data of the study. In addition to this, inferential analysis (Pearson product-moment correlation) was employed to identify any relationship that might occur between mobile phone usage and selected behavioral factors.

Table 1. The questionnaire

\begin{tabular}{lc}
\hline Parts & Number of questions \\
\hline Demographic & 10 \\
Purpose of mobile phone usage & 12 \\
Behavioral factors & 7 \\
- Performance Expectancy (PE) & 11 \\
- $\quad$ Social Influence (SI) & 5 \\
- $\quad$ Facilitating Condition (FC) & 7 \\
- $\quad$ Behavioral Intention (BI) & 6 \\
- $\quad$ Effort Expectancy (EE) & 7 \\
\hline
\end{tabular}

\section{Results and Discussion}

\subsection{Respondents' Background}

Table 2 depicts the socio-demographic data of the respondents studied. Based on the results, the majority of the respondents were male (97.2\%), Malay (92.4\%) and aged above 40 years (63.2\%). In addition, a total of 53.2\% of the respondents possess PMR/SRP/LCE and SPM/SPMV/MCE certificates, and $47.2 \%$ earn between RM701-RM1000 a month. A total of $24.8 \%$ of the respondents had over 31 years' experience as fishermen, and a total of $41.2 \%$ of respondents spent $16-20$ days a month at sea. Less than two-thirds of respondents were skippers (60.8\%), and slightly more than three-quarters (67.2\%) were zone A fishermen.

Table 2. Socio-demographic data of the respondents

\begin{tabular}{|c|c|c|c|c|}
\hline Level & Frequency & Percentage & Mean & SD \\
\hline \multicolumn{5}{|l|}{ Gender } \\
\hline Male & 243 & 97.2 & & \\
\hline Female & 7 & 2.8 & & \\
\hline \multicolumn{5}{|l|}{ Races } \\
\hline Malay & 231 & 92.4 & & \\
\hline Chinese & 7 & 2.8 & & \\
\hline Indian & 12 & 4.8 & & \\
\hline Age (years) & & & 44.1 & 13.93 \\
\hline$<25$ & 33 & 13.2 & & \\
\hline $26-40$ & 59 & 23.6 & & \\
\hline $41-55$ & 102 & 40.8 & & \\
\hline$>56$ & 56 & 22.4 & & \\
\hline \multicolumn{5}{|l|}{ Level of education } \\
\hline Never been to school & 12 & 4.8 & & \\
\hline Primary school & 98 & 39.2 & & \\
\hline PMR/SRP/LCE & 81 & 32.4 & & \\
\hline SPM/SPMV/MCE & 52 & 20.8 & & \\
\hline Skills certificates/STPM & 4 & 1.6 & & \\
\hline Diploma & 2 & 0.8 & & \\
\hline Degree & 1 & 0.4 & & \\
\hline
\end{tabular}




\begin{tabular}{|c|c|c|c|c|}
\hline Income per month & & & 922.16 & 526.97 \\
\hline$\leq \mathrm{RM} 700$ & 89 & 35.6 & & \\
\hline RM701-RM1000 & 118 & 47.2 & & \\
\hline$>$ RM1001 & 43 & 17.2 & & \\
\hline Experience as fishermen & & & 22.8 & 13.85 \\
\hline $1-5$ & 36 & 14.4 & & \\
\hline $6-10$ & 24 & 9.6 & & \\
\hline $11-20$ & 63 & 25.2 & & \\
\hline $21-30$ & 65 & 26.0 & & \\
\hline$>31$ & 62 & 24.8 & & \\
\hline Total days at sea in a month & & & 19.6 & 5.19 \\
\hline$<15$ & 57 & 22.8 & & \\
\hline $16-20$ & 103 & 41.2 & & \\
\hline $21-30$ & 60 & 24.0 & & \\
\hline $26-30$ & 30 & 12.0 & & \\
\hline \multicolumn{5}{|l|}{ Fishermen categories } \\
\hline Skipper & 152 & 60.8 & & \\
\hline Crew & 98 & 39.2 & & \\
\hline \multicolumn{5}{|l|}{ The main catch area } \\
\hline A & 168 & 67.2 & & \\
\hline B & 46 & 18.4 & & \\
\hline $\mathrm{C} 0$ & 32 & 12.8 & & \\
\hline $\mathrm{C} 2$ & 4 & 1.6 & & \\
\hline Mobile phone usage (year) & & & 8.6 & 5.410 \\
\hline $1-5$ & 89 & 35.6 & & \\
\hline $6-10$ & 97 & 38.8 & & \\
\hline$>11$ & 64 & 25.6 & & \\
\hline
\end{tabular}

\subsection{Mobile Phone Usage among Fishermen in Pangkor Island}

As can be seen in Table 3, most of the fishermen use mobile phones in case of emergencies, which is in line with a study by Omar et al. (2011). While conducting their fishing routines, fishermen are exposed to a number of risks such as engine breakdowns and sudden climate changes, and thus mobile phones can act as a safety device. The data demonstrates that mobile phones are also used for communication purposes by fishermen; fishermen use them to keep in touch with their families while they are at sea. In addition, mobile phones are used by fishermen as effective tools to communicate with colleagues, as through such communication they can share and disseminate information with regards to the location of fish. Mobile phones have also been shown to be one of the most valuable tools by which to improve market performance. Jensen (2007) proved the ability of mobile phones to improve access to market information, and the results of this study seem to support this. The analysis confirms that fishermen use mobile phones to discuss prices for their catch, and also to seek the best places and persons that offer the highest prices for their catch. Interestingly, some of the fishermen do use mobile phones for entertainment, while some of them use it for alternative communication (SMS and MMS). There are a number of reasons why advanced mobile phone applications such as games, 3G, Internet and GPS do not attract much interest from fishermen. First, as researchers have found, the majority of fishermen only possess mobile phones with common functions, whereby advance applications such as 3G, Internet and GPS are not available. Second, as most of the fishermen are older, using such advanced applications pose difficulties to them; this is not surprising, as number of previous studies have successfully proven that age and ICT applications are negatively correlated (Shaffril et al., 2010, Omar et al. 2011). 
Table 3. Mobile phone usage among fishermen in Pangkor Island

\begin{tabular}{ll}
\hline Mobile phone usage & Mean score \\
\hline For emergencies & 4.72 \\
To communicate with colleagues & 4.71 \\
To communicate with family members & 4.50 \\
To gain information on fish locations & 4.32 \\
To communicate with dealers & 3.57 \\
To gain information with regards to the places/persons that offer the best price for their catch & 3.21 \\
Watching videos/listening to music & 2.47 \\
SMS/MMS & 2.28 \\
Playing games & 1.71 \\
Gaining updated weather information & 1.69 \\
3G/surfing the Internet & 1.30 \\
Using GPS & 1.22 \\
Overall mean score & $\mathbf{2 . 9 8}$ \\
\hline
\end{tabular}

\subsection{Behavioral Factors That Influence Mobile Phone Usage among Fishermen in Pangkor Island}

Table 4 lists six behavioral factors that influence mobile phone usage among fishermen in Pangkor Island: performance expectancy, voluntariness of use, facilitating conditions, behavioral intention, social influence and effort expectancy. Performance expectancy recorded the highest mean score with $\mathrm{M}=3.95$. The second highest mean score was recorded by voluntariness of use with $\mathrm{M}=3$. 93 , followed by facilitating conditions with $\mathrm{M}=3.78$. Behavioral intention recorded a mean score of 3.34, while social influence was 3.22. The lowest mean score was recorded by effort expectancy, with a mean score of 2.86 .

Table 4. Overall level of behavioral factors

\begin{tabular}{|c|c|c|c|c|}
\hline Level & Frequency & Percentage & Mean & SD \\
\hline PE & & & 3.95 & 0.553 \\
\hline Low (1.00-2.33) & 3 & 1.2 & & \\
\hline Moderate (2.34-3.67) & 58 & 23.2 & & \\
\hline High (3.68-5.00) & 189 & 75.6 & & \\
\hline VU & & & 3.93 & 0.568 \\
\hline Low (1.00-2.33) & 85 & 34.4 & & \\
\hline Moderate (2.34-3.67) & 123 & 49.2 & & \\
\hline High (3.68-5.00) & 42 & 16.4 & & \\
\hline FC & & & 3.78 & 0.486 \\
\hline Low (1.00-2.33) & 1 & 0.4 & & \\
\hline Moderate (2.34-3.67) & 100 & 40.0 & & \\
\hline High (3.68-5.00) & 149 & 59.6 & & \\
\hline BI & & & 3.34 & 0.774 \\
\hline Low (1.00-2.33) & 22 & 8.8 & & \\
\hline Moderate (2.34-3.67) & 134 & 53.6 & & \\
\hline High (3.68-5.00) & 94 & 37.6 & & \\
\hline
\end{tabular}


SI

Low (1.00-2.33)

Moderate (2.34-3.67)

High (3.68-5.00)

EE

Low (1.00-2.33)

Moderate (2.34-3.67)

High (3.68-5.00)
3.22

0.357

$0 \quad 0$

$221 \quad 88.4$

$29 \quad 11.6$

2.86

0.860

34.4

49.2

16.4

\subsection{Relationship between Mobile Phone Usage and Constructs Studied}

Based on the data in Table 5, it can be seen that four out of the six constructs studied were identified as having a significant relationship with mobile phone usage. PE $(r=.671)$ and $\mathrm{EE}(\mathrm{r}=.588)$ were identified to have moderate and positive relationships with mobile phone usage, while BI $(r=.342)$ and SI $(r=.256)$ were identified to have low and positive relationships with mobile phone usage.

$\mathrm{PE}$ has been consistently identified as a major contributor towards technology usage among communities (Abu Hassan et al., 2011; Mohd Suki and Mohd Suki, 2011; Laudon and Laudon, 2000). Laudon and Laudon (2000) show that communities perceive a technology as beneficial to them if it enables them to increase their productivity, gather large amounts of information within a short time, consume minimal cost and easily connect them to the community; thus, it is not surprising that PE is positively associated with fishermen's mobile phone usage here, as the technology enables them to consume less time, money and energy via information sharing, while reducing their vulnerability towards certain threats during their fishing operations.

Additionally, EE was identified to have a positive and moderate relationship with fishermen's mobile phone usage. The data gained is in tandem with that found by Ramayah and Ignatius (2005), who accentuated that people will start to use technology if it is easy to use, and stop using it if it starts to pose difficulties for them. Moreover, Ramayah and Ignatius (2005) stressed that enjoyment is an important aspect to consider, as a lack of enjoyment can impinge on EE towards technology usage.

BI was another construct with a positive and low relationship with fishermen's mobile phone usage. BI is hugely affected by attitude (Zhang and Aikman, 2007). Shiro (2008) provides a simple explanation with regards to the role of attitude on technology usage, in that those with a positive attitude will use the technology, and those with negative attitude will hesitate to do so.

It is not surprising that SI can inhibit mobile phone usage among fishermen. A study conducted by Gilligan (2005) confirms that SI is a crucial factor for encouraging people to use technology by accentuating that people who are surrounded by a community who actively use technology will be influenced to use the same technology. Additionally, Rouibah (2008) stresses that people will adopt certain technologies based on perceptions that people close to them have adopted it and expect them to use it.

Table 5. Pearson correlations

\begin{tabular}{lcc}
\hline Variables & $P$ & $r$ \\
\hline PE & .0001 & .671 \\
EE & .0001 & .588 \\
BI & .0001 & .342 \\
SI & .0001 & .287 \\
FC & .2560 & .072 \\
VU & .8870 & -.009 \\
\hline
\end{tabular}

\section{Conclusion and Recommendation}

Mobile phones have been proven to profit various groups, and fishermen represent one of them. For Pangkor Island fishermen, mobile phones are useful devices, as they assist them in their fishing operations, particularly 
with respect to safety, communication, marketing and entertainment. Further analysis confirms that four behavioral factors, namely PE, EE, BI and SI have positive and significant relationships with fishermen's mobile phone usage. Based on such data, this study provides a number of recommendations. First, it is the responsibility of the government to motivate and embolden the fishermen to use mobile phone and one of the ways is by conducting persistent courses and seminars and Abu Hassan et al. (2009) has concluded on the effectiveness of such efforts in encouraging the community particularly those in the rural areas to use technology more in their life. Such effort furthermore will educate and inform fishermen on mobile phones, particularly with respect to applications that are new to them. In turn, this might create a better perception among fishermen of the benefits and ease of mobile phone usage. Such courses and seminars are crucial, as focusing on basic mobile phone usage alone (i.e. calling and messaging) while forsaking other applications will transform positive ease of use into negative. Teo (2008) states that having access to an abundance of technology applications will be a waste if they are not used. Unused applications will be perceived as less beneficial by the non-users, though they actually have a lot to offer.

Second, government subsidies for buying a mobile phone for the fishermen is seen as a good effort in motivating them to use the mobile phone more in their fishing routine. Though, they are some subsidy given by the government in buying telecommunication tool, such subsidy is restricted only to Smartphone and it should be extended to common mobile phone too. Promotions should be intensified, as a lack of marketing can inhibit fishermen's SI and BI to use technology such as mobile phones (Abu Hassan et al., 2010; Shaffril et al., 2010). This effort should be overseen by leading fisheries agencies in Malaysia such as the National Fishermen Association (PNK), Department of Fisheries Malaysia (DOF) and Fisheries Development Authority of Malaysia (LKIM). Promotion can be done via a number of channels, and in the case of fishermen, as suggested by Hassan et al. (2011), interpersonal sources such as village leaders, agency officers, fishermen's colleagues and family members can be a good source of promotion as they are trusted and considered reliable sources by the agriculture community, particularly in rural areas. Informal means of promotion can also be an effective tool. Officers and village leaders can chat with fishermen in an informal manner at community locations (such as coffee stalls) regarding the benefits and importance of mobile phones for fishing operations. Other channels, such as television and radio, and print media such as brochures and pamphlets, also represent good alternatives (Hassan et al. 2011). Promotion via the Internet is ineffective, according to Omar et al. (2011), as not too many fishermen in Malaysia rely on the Internet as a source through which to obtain fishing information. Perhaps, this research will provide a great foundation for other to conduct research with regard to fishermen particularly on their mobile phone usage. A specific research is required to further investigate the impacts of PE, EE, BI and SI on fishermen mobile phone usage. The main limitation of this research is that it covers only fishermen from Pangkor Island and the result might be different if fishermen from other areas are included as the respondents.

\section{References}

Abu Hassan, M., Abu Samah, B., Shaffril, H. A. M., \& D’Silva, J. L. (2011). Perceived usefulness of ICT usage among JKKK members in Peninsular Malaysia. Asian Social Science, 7(10), 255-266. http://dx.doi.org/10.5539/ass.v7n10p255

Abu Samah, B., Shaffril, H. A. M., D'Silva, J. L., \& Abu Hassan, M. (2010). Information communication technology, village development and security committee and village vision movement: a recipe for rural success in Malaysia. Asian Social Science, 6(4), 136-144.

Argawal, R., \& Prasad, J. (1999). Are individual difference germane to the acceptance of new information technologies? Decision Science, 30(2), 361-391. http://dx.doi.org/10.1111/j.1540-5915.1999.tb01614.x

Department of Fisheries Malaysia. (2010). Number of fishermen working on licensed fishing vessels. Retrieved November 6, 2012, from http://www.dof.gov.my/c/document_library/get_file?uuid=3e973437-e71e-4428-b528-fbb01ba60be7\&grou pId $=952434$

Gilligan, R. (2005). Questioning the "rural" adoption and use of ICTs. Computer Science, 32(5), 155-167.

Hassan, M. S., Yassin, S. M., Shaffril, H. A. M., Othman, M. S., Abu Samah, B., Abu Samah, A., \& Ramli, S. A. (2011). Receiving the agriculture information through mass media and interpersonal sources among the rural community. American Journal of Agriculture and Biological Science, 6(3), 451-461. http://dx.doi.org/10.3844/ajabssp.2011.451.461

Jensen, R. (2007). The digital provide: information (technology), market performance, and welfare in the South Indian fisheries sector. Quarterly Journal of Economics, 122(3), 879-924. 
http://dx.doi.org/10.1162/qjec.122.3.879

Laudon, K. C., \& Laudon, J. P. (2000). Management information systems: organization and technology in the networked enterprise (6th ed.). Prentice-Hall, Englewood Cliffs, NJ.

Meso, P., Musa, P., \& Mbarika, V. (2005). Towards a model of consumer use of mobile information and communication technology in LDCs: The case of Sub-Saharan. African Information Systems, 15, 119-146. http://dx.doi.org/10.1111/j.1365-2575.2005.00190.x

Mohammad Najib, A. G. (1999). Skudai Educational Research. University Teknology of Malaysia, Skudai, Johor.

Noor Sharifah, S. S. (2006). ICT centers for rural community in Peninsular Malaysia. Inaugural Lecture Series. Technology University of Malaysia Publisher, Skudai Johor.

Nunnally, J. C. (1978). Psychometric theory (2nd ed.). Mc-Graw Hill, New York.

Omar, S. Z., Abu Hassan, M., Shaffril, H. A. M., Bolong, J., \& D'Silva, J. L. (2011). Information and communication technology for fisheries industry development in Malaysia. African Journal of Agriculture Research, 6(17), 4166-4176.

Oye, N. D., Iahad, A. N., \& Rabin, A. N. (2012). Behavioral intention to accept and use ICT in public universities: integrating quantitative and qualitative data. Journal of Emerging Trends in Computing and Information Sciences, 3(6), 957-969.

Ramayah, T., \& Ignatius, J. (2005). Impact of perceived usefulness, perceived ease of use and perceived enjoyment on intention to shop online. ICFAI Systems Management, 3(3), 36-51.

Rogers, E. M. (2003). Diffusion of innovations (5th ed.). The Free Press, New York.

Rouibah, K. (2008). Social usage of instant messaging by individuals outside the workplace in Kuwait. Information Technology and People, 21(1), 34-68. http://dx.doi.org/10.1108/09593840810860324

Salia, M., Nicholas, N. N., Nsowah-Nuamah, \& William, F. S. (2011). Effects of mobile phone use on artisanal fishing market efficiency and livelihoods in Ghana. The Electronic Journal on Information Systems in Developing Countries, 47(6), 1-26.

Shaffril, H. A. M., Abu Samah, B., Abu Hassan, M., \& D'Silva, J. L. (2010). Socio-economic factors that impinge computer usage in administration works among village leaders in Malaysia. Scientific Research and Essays, 5(23), 3623-3633.

Shiro, U. (2008). A case study of DIY ICT. Information, 10(4), 46-60.

Teo, T. (2008). Pre-services teacher attitude towards computer use: a Singapore survey. Australasian Educational Technology, 24(4), 413-424.

Venkatesh, V., Morris, M. G., Davis, G. B., \& Davis, F. D. (2003). User acceptance of information technology: toward a unified view. MIS Quarterly, 27(3), 425-478.

Zhang, P., \& Aikman, S. (2007). Attitudes in ICT acceptance and use. Human-Computer Interaction, 4550, 1021-1030. 